\title{
Supplement with Cystoseira canariensis promotes an increase of resistance to the maximum load in the grastrocnemius muscle of female rats
}

\author{
Suplemento com Cystoseira canariensis promove aumento de resistência à carga \\ máxima em músculo gastrocnêmio de ratas
}

Suplemento con Cystoseira canariensis promueve aumento de la resistencia a la carga máxima en músculo gastrocnemio de ratas

Douglas Reis Abdalla', Eliana Silva Cassimiro Araújo², Leonardo César Carvalho³, Dernival Bertoncello ${ }^{4}$

\begin{abstract}
I Was evaluated the maximum load supported by the grastrocnemius muscle of female rats after the ministering of Cystoseira canariensis, either associated or not to swimming. Twenty-eight young Wistar female rats were used, divided into 4 groups: control (C, n=7); supplement (S, $\mathrm{n}=7$ ); supplement and swimming (SSw, n=7); swimming (Sw, $\mathrm{n}=7$ ). Each one pertaining to the groups $S$ and SSw received $20 \mathrm{mg}$ of myostatin inhibitor per day. The swimming consisted in an aerobe protocol, three times in a week, during eight weeks. The right grastrocnemius muscle of each animal was removed and a tension test was performed in an Emic testing machine. The results (Mean \pm SEM) were evaluated through ANOVA and Tukey test $(p<0.05)$. A significant difference for maximum load (in N) was verified among the groups C (35.41 \pm 1.06$)$ and S (39.98 \pm 1.15$)$; Sw (27.94 \pm 2.19$)$ and S (39.98 \pm 1.15$)$; Sw $(27.94 \pm 2.19)$ and SSw $(37.78 \pm 1.28)$. In relation to the stretching at the maximum limit (in $\times 10^{-3} \mathrm{~m}$ ) at the maximum load, the group SSw obtained a value $(20.68 \pm 1.19)$ significantly greater than the groups C $(17.15 \pm 1.11), S$ and Sw (16.11 1.60$)$. There was a significant difference for body weight gain among the groups treated with supplement and supplement associated to the swimming, with smaller values for this last. The myostatin inhibitor either, associated or not to the swimming, promotes an increase of resistance to the maximum load in the tension test in grastrocnemius muscle of young female rats.
\end{abstract}

Keywords I Myostatin; Swimming; Muscle Strength; Rats, Wistar.

RESUMO I O objetivo deste trabalho foi avaliar a carga máxima suportada pelo músculo gastrocnêmio de ratas após intervenção com Cystoseira canariensis, associado ou não à natação. Foram utilizadas 28 ratas Wistar, divididas em 4 grupos: controle (C, $n=7$ ); suplemento ( $S, n=7$ ); suplemento e natação ( $S N, n=7)$; e natação ( $N, n=7)$. Cada animal pertencente aos grupos S e SN recebeu 20 mg de inibidor de miostatina por dia. A natação consistiu em um protocolo aeróbio, três vezes por semana, durante oito semanas. Após o período de treinamento, foi retirado o músculo gastrocnêmio direito de cada animal e realizado teste de tração em uma máquina de ensaio Emic. Os resultados (Média \pm DP) foram avaliados por meio de ANOVA e teste de Tukey $(p<0,05)$. Houve diferença significativa para carga no limite máximo (em $N$ ) entre os grupos C $(35,41 \pm 1,06)$ e S (39,98 $\pm 1,15) ; N(27,94 \pm 2,19)$ e S (39,98 $\pm 1,15) ; N(27,94 \pm 2,19)$ e SN $(37,78 \pm 1,28)$. Em relação ao alongamento no limite máximo (em x10 $\left.{ }^{-3} \mathrm{~m}\right)$, o grupo SN obteve valor $(20,68 \pm 1,19)$ significativamente maior do que os grupos C $(17,15 \pm 1,11)$ e $N(16,11 \pm 1,60)$. Houve diferença significativa para ganho de massa corporal entre os grupos tratados com suplemento e suplemento associado à natação, com menores valores para este último. $\mathrm{O}$ inibidor de miostatina, associado ou

Study carried out in the Bioengineering Laboratory of Universidade de Uberaba (UNIUBE) - Uberaba (MG), Brazil. 1Physical Therapist; Professor at Faculdade de Talentos Humanos (FACTHUS) - Uberaba (MG), Brazil. ${ }^{2}$ Odontologist; Professor at UNIUBE - Uberaba (MG), Brazil.

${ }^{3}$ Physical Therapist; Adjunct Professor at Universidade Federal de Alfenas (UNIFAL) - Alfenas (MG), Brazil. ${ }^{4}$ Physical Therapist; Adjunct Professor at UFTM - Uberaba (MG), Brazil. 
não à natação, promove aumento de resistência à carga máxima, no teste de tração, em músculo gastrocnêmio de ratas jovens.

Descritores I Miostatina; Natação; Força Muscular; Ratos Wistar.

RESUMEN I El objetivo de este trabajo fue evaluar la carga máxima soportada por el músculo gastrocnemio de ratas después de intervención con Cystoseira canariensis, asociado o no con la natación. Se utilizaron 28 ratas Wistar, divididas en 4 grupos: control (C, $n=7)$; suplemento (S, n=7); suplemento y natación (SN, n=7); y natación ( $N$, n=7). Cada animal perteneciente a los grupos S y SN recibió 20 mg de inhibidor de miostatina por día. La natación consistió em un protocolo aeróbico, tres veces por semana, durante ocho semanas. Tras el período de entrenamiento, fue retirado el músculo gastrocnemio derecho de cada animal y realizado test de tracción en una máquina de ensayo Emic. Los resultados (Media \pm DP) fueron evaluados por ANOVA y test de Tukey $(p<0,05)$. Hubo una diferencia significativa en

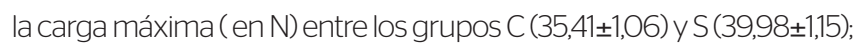
N (27,94 $\pm 2,19)$ y S (39,98 $\pm 1,15) ; N(27,94 \pm 2,19)$ y SN $(37,78 \pm 1,28)$. En cuanto al alargamiento en el límite máximo (en x10-3 m), el grupo SN obtuvo valor $(20,68 \pm 1,19)$ significativamente mayor que los grupos C $(17,15 \pm 1,11)$ y $N(16,11 \pm 1,60)$. Hubo una diferencia significativa en el aumento de masa corporal entre los grupos tratados con suplemento y suplemento asociado con la natación, con valores más bajos para este último. El inhibidor de miostatina, asociado o no con la natación, promueve aumento de resistencia a la carga máxima, en el test de tracción, en músculo gastrocnemio de ratas jóvenes.

Palabras clave I Miostatina; Natación; Fuerza Muscular; Ratas Wistar.

\section{INTRODUCTION}

The hypertrophy of the skeletal muscle is a result of individual growth in the cross-sectional region of muscle fibers that results in the enlargement of its cross-sectional section, which, on the other hand, is a reflex of the growing number and size of myofibrils and the adaptation of sarcomeres inside the muscle fiber ${ }^{1}$. Among the mechanisms that are in charge of controlling the increasing size of the muscle fiber, it is important to consider myostatin, since it is a potent regulator of growth and myoblast differentiation ${ }^{2}$.

Myostatin is initially expressed during the formation of the musculoskeletal cell, being known as a growing differentiator-8 (GDF-8), from the superfamily of the tumor growing factor beta (TGF- $\beta$ ). It inhibits the increasing muscle trophism by inactivating the myoblasts and satellite cells ${ }^{3-6}$.

In the skeletal muscle, myostatin is transcribed as a messenger RNA (mRNA), which codified a precursor protein containing 335 amino acids. In adult rats, myostatin circulates in its a latent form in the blood flow, and it can be activated in an acid environment, similarly to TGF- $\beta$. The excessive expression of systemic myostatin among adult female rats induces deep muscle mass and fat loss, without, however, decreasing the absorption of nutrients ${ }^{7}$. Also, the decreasing mRNA expression has been identified for myostatin in the skeletal muscle of rats exposed to physical training ${ }^{8}$.

There are only a few indicators of myostatin inhibitors in literature, even though they have been considered as probable candidates to genic therapy ${ }^{9-11}$. Studies suggest that supplementation containing Cystoseira canariensis can promote the loss of body fat mass and gain of muscle mass, once this compound, which is a derivative of brown seaweed, would be connected to myostatin and, apparently, it could reduce the biological effects of this protein ${ }^{12-14}$. However, no studies approaching the effect of this supplementation on the resistance and muscle strength of rats have been found. Its importance for muscle mass control is in accordance with the need to develop studies focused on strength loss situations, be it due to lack of use or the absence of protein filaments inside the myofibrils, or be it due to some specific diseases, syndromes or aging ${ }^{15,16}$.

The objective of this study was to verify the possible effect of the supplementation with Cystoseira canariensis, associated or not to swimming, on body mass and traction force of the gastrocnemius muscles in female rats.

\section{METHODOLOGY}

\section{Animals}

This study was characterized as being randomized and experimental. Twenty-eight female Wistar rats were used. They were 45 days old, with body mass of approximately $250 \mathrm{~g}$, coming from and maintained in the Central Bioterium of UNIUBE. The animals were kept under a light regime (10 hours, bright, 14 hours, dark) and controlled temperature $\left(25^{\circ} \mathrm{C}\right)$. They were divided in four groups: control $(\mathrm{C}, \mathrm{n}=7)$, without swimming or supplementation; supplementation $(\mathrm{S}, \mathrm{n}=7)$, with supplementation; supplementation associated with swimming (SSw, $n=7$ ); they underwent the exercise protocol and received supplementation in the period; and swimming 
(Sw, n=7) - these were only submitted to the swimming protocol.

In order to conduct this study, according to the guidelines of the Research Ethics Committee, all of the principles proposed by some authors and ratified by UNESCO were obeyed. In 1978, UNESCO elaborated the Declaration of Animal Rights. The experiment was in accordance with all of the necessary precautions to avoid the suffering of each animal ${ }^{17,18}$. The project was approved by the Commission of Animal Experimentation of UNIUBE (Process n. 028/2009).

Treatment and exercise protocol

Animals in groups $\mathrm{S}$ and Ssw were treated with $20 \mathrm{mg}$ of the Myoblast ${ }^{\mathrm{TM}}$ supplement, which contains Cystoseira canariensis, diluted in water, in a daily dose for 8 weeks, six days a week.

Animals were trained with moderate chronic aerobe exercise (swimming), three times a week, on alternate days, for eight weeks, based on a protocol adapted from several authors ${ }^{19,20}$. The temperature of the water was maintained between $30^{\circ}$ and $35^{\circ} \mathrm{C}$, being changed daily. During the swimming period, time increased progressively. On the first day, it lasted 15 minutes; on the second day, 15 other minutes were added, and so on, successively, until the total time of 45 minutes. During the swimming activity, which was conducted in a tank measuring $1.5 \times 0.90 \times 0.70 \mathrm{~m}$, the animal had overload ( $5 \%$ of body mass) attached to its tail.

\section{Studied variables}

\section{Body mass}

Throughout the eight weeks of treatment, body mass values of the animals were verified weekly, in order to prepare the load that would be attached to the tail and to assess the probable weight gain. After the eight weeks, animals were euthanized with anesthetic overdose.

\section{Muscle tissue analysis}

\section{Traction trial}

The traction trial consisted of the collection of the set right femur-gastrocnemius, calcaneus of female rats. The universal testing machine $\mathrm{EMIC}^{\circledR}$ - model DL3500, from the Laboratory of Odontology Material Research, at Universidade de Uberaba, equipped with a load cell of $50 \mathrm{kgf}$, was used to execute the mechanical trial. The machine was directly connected to a microcomputer equipped with software that was able to obtain accurate load and stretching values. A special device was used to fixate and conduct the muscle traction trials, so that the muscle origin and insertion could be preserved.

The parameters adopted for the trial were: preload of $0.30 \mathrm{kgf}$, trial velocity of $10 \mathrm{~mm} / \mathrm{min}$; load limits and stretching of $8.00 \mathrm{kgf}$ and $25 \mathrm{~mm}$, respectively. After the conduction of each trial, the place of muscle fiber rupture was observed. For each load increase applied to the muscle, there was a resulting stretching value, which enabled the construction of graphics showing load versus stretching, by using the software Microsoft Excel Xp Professional ${ }^{\circledR}$.

Afterwards, the following mechanical properties were analyzed: load at maximum limit; stretching at maximum limit; and rigidity ${ }^{21-24}$.

\section{Statistical analysis}

The ANOVA test was used for the simultaneous analysis of groups, and the Tukey-Kramer test was used to compare both groups; a significance level lower than 5\% was adopted.

\section{RESULTS}

A significant difference was observed for body mass gain between the groups treated with supplementation and supplementation associated with swimming, with lower values for the latter (Table 1).

In Table 1, values referring to load limit (LL) and maximum stretch limit (MSL) presented by the gastrocnemius muscle of the animals were observed. At the end of the experimental period, higher MSL values were observed for the SSw group, in comparison to the $\mathrm{Sw}$ group. Concerning LL, the SSw group presented higher values than experimental groups C, S and Sw.

Table 1. Body mass gain (g), maximum load ( $\mathrm{Sw}$ ), maximum stretch limit $\left(\times 10^{-3} \mathrm{~m}\right)$ and rigidity $\left(\times 10^{3} \mathrm{~N} / \mathrm{m}\right)$ in groups $(\mathrm{C}),(\mathrm{S}),(\mathrm{Sw})$ and $(\mathrm{SSw})(\mathrm{mean} \pm \mathrm{SD})$

$\begin{array}{lcccc}\text { Group } & \text { Mass gain } & \begin{array}{c}\text { Maximum } \\ \text { load }\end{array} & \begin{array}{c}\text { Maximum } \\ \text { stretch limit }\end{array} & \text { Rigidity } \\ \text { C } & 67.5 \pm 15.01 & 35.41 \pm 1.06 & 17.15 \pm 1.11 & 3.07 \pm 0.31 \\ \text { S } & 92.3 \pm 18.04^{*} & 39.98 \pm 1.15^{*} & 18.71 \pm 2.31 & 3.22 \pm 0.28^{* *} \\ \text { SW } & 64.0 \pm 11.11^{* *} & 27.94 \pm 2.19 & 16.11 \pm 1.60 & 2.06 \pm 0.29 \\ \text { SSW } & 59.7 \pm 25.02 & 37.78 \pm 1.28^{* * * *} & 20.68 \pm 1.19^{* * * * *} & 2.83 \pm 0.63\end{array}$

* $\mathrm{p}<0.05$ versus $\mathrm{C}$ (Control); ** $\mathrm{p}<0.05$ versus Sw (Swimming); ${ }^{* * *} \mathrm{p}<0.05$ versus SSw

(Supplementation and Swimming); ${ }^{* * * *} p<0.05$ versus Sw ; ${ }^{* * * *} p<0.05$ versus $\mathrm{C}$ and SSW 
Rigidity value was significantly lower for the group that only swam, compared to the group that only received supplementation. For this property, no significant differences were found between the other groups.

\section{DISCUSSION}

The objective of this study was to verify the possible variation in body mass and in the gain of resistance of the gastrocnemius muscle, among female rats in the traction test after a period of physical training with or without a supplementation containing a myostatin inhibitor. Even though literature presents relevant work related to genic therapy and therapeutics to increase muscle mass ${ }^{11,25}$, no studies were observed that identified the variation of body mass in animals treated with myostatin inhibitor. It is worth to mention that the aerobe exercise protocol was used, what would favor body mass loss. The myostatin inhibitor seems to have an anabolic effect on animals, which may have had strong action when not being associated with any therapy.

The myostatin inhibitor used in this work contained Cystoseira canariensis, a polysaccharide deriving from brown seaweeds which with a complex group of macromolecules. This would facilitate its connection with myostatin and, consequently, the inactivation of this protein. There are also records that these polysaccharides regulate some growing factors and cytokines, such as fibroblast growth factors, interferon, and some enzymes belonging to the family of TGF- $-b^{12,26}$.

In a study conducted with humans by Willoughby ${ }^{13}$, who used supplements containing Cystoseira canariensis combined with physical exercise, it was not possible to observe increasing strength and muscle mass, when compared to the group that performed training without supplementation. The amount used in this study could have been enough to generate such changes in female rats, unlike the mentioned study, since the growth mechanism of the skeletal muscle is similar both for humans and rats.

The implication of this study may be extended to cases in which there is the need to maintain muscle mass in specific diseases, which lead to strength loss ${ }^{27-29}$. Bogdanovich et al. ${ }^{30}$ tested myostatin inhibition in vivo in $\mathrm{mdx}$ mice, and results revealed increasing weight, mass, size and absolute muscle strength, with significant decrease in muscle degeneration. They concluded that myostatin blockade offers treatments for diseases associated with muscle loss, for instance, Duchenne muscle dystrophy. The expression of the GDF-8 gene is similar in muscle tissues of patients with two types of muscle dystrophy (Duchenne and Becker), with different levels of clinical compromise ${ }^{31}$.

In a recent study, a swimming protocol was applied (45 minutes, twice a day, for 4 weeks) to rats submitted or not to a diet with high fat level. Animals who swam and were not under a special diet presented significant reduction in the mRNA expression for myostatin in the analyzed gastrocnemius muscle, in comparison to the group that did not exercise; but the result was not repeated when groups who received a fat-rich diet were compared ${ }^{32}$. The swimming protocol used in this study may have been potentialized by the use of a supplement with Cystoseira canariensis.

These findings indicate a higher maximum load supported by the muscles of rats that received supplementation, be it compared to groups $\mathrm{C}$ or $\mathrm{Sw}$. For the $\mathrm{S}$ group, it is possible that the mass gain also contributed with the increasing resistance to the conducted traction test. However, the group that swam and received supplement had gained less body mass, but presented with resistance to the maximum load when compared to the $\mathrm{S} w$ group, not differing from the $\mathrm{C}$ group.

In relation to maximum stretch limit, groups that received supplementation (isolated or associated with swimming) were the ones that presented higher values. When it is possible to observe that the muscles stretch more with the load at the maximum limit, it becomes more rigid, which is a reflection of the elastic phase of the muscle. This occurred with the group that received only the supplementation. This result is a positive indication of the action of Cystoseira canariensis on the muscle, once higher values were also observed for the maximum load in these muscles, making them more resistant to lesion and/or rupture. This resistance has been observed by other authors by other authors, and it indicates that the traction trial is a form of analysis to preserve the physiological aspects of the muscle ${ }^{24,33,34}$.

The fact that the gastrocnemius muscle of animals who received Cystoseira canariensis presented better results for the studied mechanical properties indicates a possible change in the structure of this muscle 
among female rats, which could not be confirmed due to the lack of histological analysis - a limitation of this study. However, supplementation proved to be efficient during these eight weeks of treatment when it comes to the performance of the muscle facing the imposition of the traction load.

\section{CONCLUSION}

The supplement containing myostatin inhibitor seems to have an anabolic effect on the muscle of the animals, including in the contribution for body mass gain. Also, associated or not to swimming, it promotes increasing resistance to the maximum load, in the traction test, in the gastrocnemius muscle of younger female rats, which becomes a positive indication for the improving muscle performance.

\section{REFERENCES}

1. Meloni VHM. O papel da hiperplasia na hipertrofia do músculo esquelético. Rev Bras Cine Des Hum. 2005;7(1):59-63.

2. Yamada AK, Verlengia R, Bueno Junior CR. Myostatin: genetic variants, therapy and gene doping. Braz J Pharm Sci. 2012;48(3):369-77.

3. McCroskery S, Thomas M, Maxwell L, Sharma M, Kambadur R. Myostatin negatively regulates satellite cell activation and selfrenewal. J Cell Biol. 2003;162(6):1135-47.

4. Thomas M, Langley B, Berry C, Sharma M, Kirk S, Bass J, et al. Myostatin, a negative regulator of muscle growth, functions by inhibiting myoblast proliferation. J Biol Chem. 2000;275(51):40235-43.

5. Gilson H, Schakman O, Kalista S, Lause P, Tsuchida K, Thissen JP. Follistatin induces muscle hypertrophy through satellite cell proliferation and inhibition of both myostatin and activin. Am J Physiol Endocrinol Metab. 2009;297(1):E157-E64.

6. Lee SJ, Huynh TV, Lee YS, Sebald SM, Wilcox-Adelman SA, Iwamori N, et al. Role of satellite cells versus myofibers in muscle hypertrophy induced by inhibition of the myostatin/activin signaling pathway. Proc Natl Acad Sci U S A. 2012:109(35):E2353-60.

7. Hamrick MW, McPherron AC, Lovejoy CO. Bone mineral content and density in the humerus of adult myostatin-deficient mice. Calcif Tissue Int. 2002;71(1):63-8.

8. Matsakas A, Bozzo C, Cacciani N, Caliaro F, Reggiani C, Mascarello $\mathrm{R}$, et al. Effect of swimming on myostatin expression in white and red gastrocnemius muscle and in cardiac muscle of rats. Exp Physiol. 2006;91(6):983-94.

9. Schuelke M, Wagner KR, Stolz LE, Hubner C, Riebel T, Komen W, et al. Myostatin mutation associated with gross muscle hypertrophy in a child. N Engl J Med. 2004;350(26):2682-8.

10. Artioli GG, Hirata RDC, Lancha Junior AH. Terapia gênica, doping genético e esporte: fundamentação e implicações para o futuro. Rev Bras Med Esporte. 2007:13(5):349-54.
11. Candena SM, Tomkinson KN, Monnell TE, Spaits MS, Kumar R, Underwood KW, et al. Administration of a soluble activin type II B receptor promotes skeletal muscle growth independent of fiber type. J Appl Physiol (1985). 2010;109(3):635-42.

12. Ramazanov Z, Jimenez del Rio M, Ziegenfuss T. Sulfated polysaccharides of brown seaweed Cystoseira canariensis bind to serum myostatin protein. Acta Physiol Pharmacol Bulg. 2003:27(2-3):101-6.

13. Willoughby DS. Effects of heavy resistance training on myostatin mRNA and protein expression. Med Sci Sports Exerc. 2004;36(4):574-82.

14. Williams M. Dietary Supplements and Sports Performance: Herbals. JISSN. J Int Soc Sports Nutr. 2006;3(1):1-6.

15. Krivickas LS, Walsh R, Amato AA. Single muscle fiber contractile properties in adults with muscular dystrophy treated with MYO-029. Muscle Nerve. 2009;39(1):2-9.

16. LeBrasseur NK, Schelhorn TM, Bernardo BL, Cosgrove PG, Loria PM, Brown TA. Myostatin inhibition enhances the effect of exercise on performance and metabolic outcomes in aged mice. J Gerontol A Biol Sci Med Sci. 2009;64(9);940-8.

17. Russell WMS, Burch RL. The Principles of Humane Experimental Technique. London: Methuen;1959.

18. Zimmermann M. Ethical Guidelines for Investigations of Experimental Pain in Conscious Animals. Pain. 1983;16(2):109-10.

19. Takeda N, Ohkubo T, Nakamura I, Suzuki H, Nagano M. Mechanical catecholamine responsiveness and myosin isoenzyme pattern of pressure-overloaded rat ventricular myocardium. Basic Res Cardiol. 1987;82(4):370-4.

20. Pestana PRD, Alves AN, Fernandes KPS, Silva Junior JA, França $\mathrm{CR}$, Martins MD, et al. Efeito da natação na expressão de fatores regulatórios miogênicos durante o reparo do musculoesquelético de rato. Rev Bras Med Esporte. 2012;18(6):419-22.

21. Matheus JPC, Milani JGPO, Gomide LB, Volpon JB, Shimano AC. Análise biomecânica dos efeitos da crioterapia no tratamento da lesão muscular aguda. Rev Bras Med Esporte. 2008;14(4):372-5.

22. Carvalho LC, Polizello JC, Padula N, Freitas FC, Shimano AC, Mattiello-Sverzut AC. Propriedades mecânicas do gastrocnêmio eletroestimulado pós-imobilização. Acta Ortop Bras. 2009;17(5):269-72

23. Abdalla D, Bertoncello D, Carvalho LC. Avaliação das propriedades mecânicas do músculo gastrocnêmio de ratas imobilizado e submetido à corrente russa. Fisioter Pesq. 2009;16(1):59-64.

24. Kodama FY, Camargo RCT, Job AE, Osaki GAT, Koike TE, Camargo Filho JCS. Propriedades mecânicas do músculo de ratos adultos e idosos, exercitado pós-imobilização. Acta Ortop Bras. 2012;20(4):218-22.

25. Oliveira RS, Collares TS, Smith KR, Collares TV, Seixas FK. The use of genes for performance enhancement: doping or therapy? Braz J Med Biol Res. 2011;44(12):1194-201.

26. Lee SJ, McPherron AC. Regulation of myostatin activity and muscle growth. Proc Natl Acad Sci USA. 2001;98(16):9306-1.

27. Sumner CJ, Wee CD, Warsing LC, Choe DW, Ng AS, Lutz C, et al. Inhibition of myostatin does not ameliorate disease features of severe spinal muscular atrophy mice. Hum Mol Gen. 2009;18(17):3145-52.

28. Bogdanovich S, Perkins KJ, Krag TO, Whittemore LA, Khurana TS. Myostatin propeptide-mediated amelioration of dystrophic pathophysiology. FASEB J. 2005:19(6):543-54. 
29. Qiao C, Li J, Jiang J, Zhu X, Wang B, Li J, et al. Myostatin propeptide gene delivery by adeno-associated virus serotype 8 vectors enhances muscle growth and ameliorates dystrophic phenotypes in mdx mice. Hum Gen Ther. 2008:19(3):241-54.

30. Bogdanovich S, Perkins KJ, Krag TO, Khurana TS. Therapeutics for Duchenne muscular dystrophy: Current approaches and futures directions. J Mol Med (Berl). 2004;82(2):102-15.

31. Costa CS. Estudo da expressão do gene GDF-8 em tecido muscular de camundongos distróficos mdx e nas distrofias Xp21 humanas [Dissertação de Mestrado]. São Paulo: Instituto de Biociências da Universidade de São Paulo; 2002. 79p.
32. Bueno PG, Bassi D, Contrera DG, Carnielli HM, Silva RN, Nonaka $\mathrm{KO}$, et al. Post-exercise changes in myostatin and actRIIB expression in obese insulin-resistant rats. Mol Cell Endocrin. 2001;339(1-2):159-64

33. Järvinen $M$, Einola SA, Virtanen EO. Effect of the position of immobilization upon the tensile properties of the rat gastrocnemius muscle. Arch Phisys Med Rehabil.1992;73(3):253-7.

34. Carvalho LC, Shimano AC, Picado CHF. Estimulação elétrica neuromuscular e o alongamento passivo manual na recuperação das propriedades mecânicas do músculo gastrocnêmio imobilizado. Acta Ortop Bras. 2008:16(3):161-4. 